
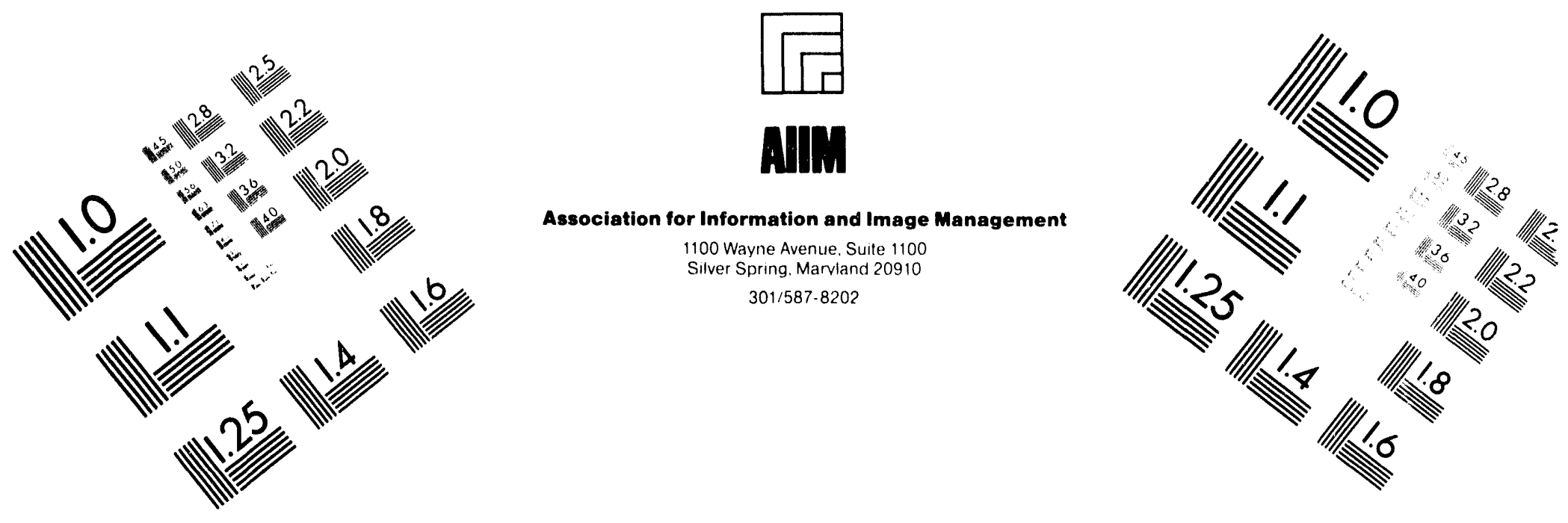

\title{
Centimeter
}

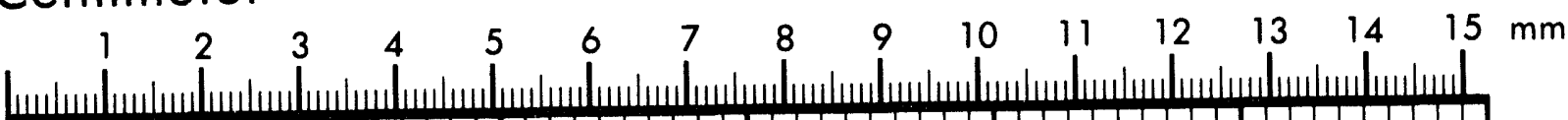

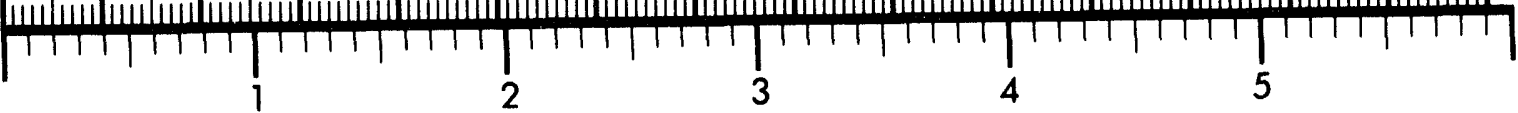
Inches
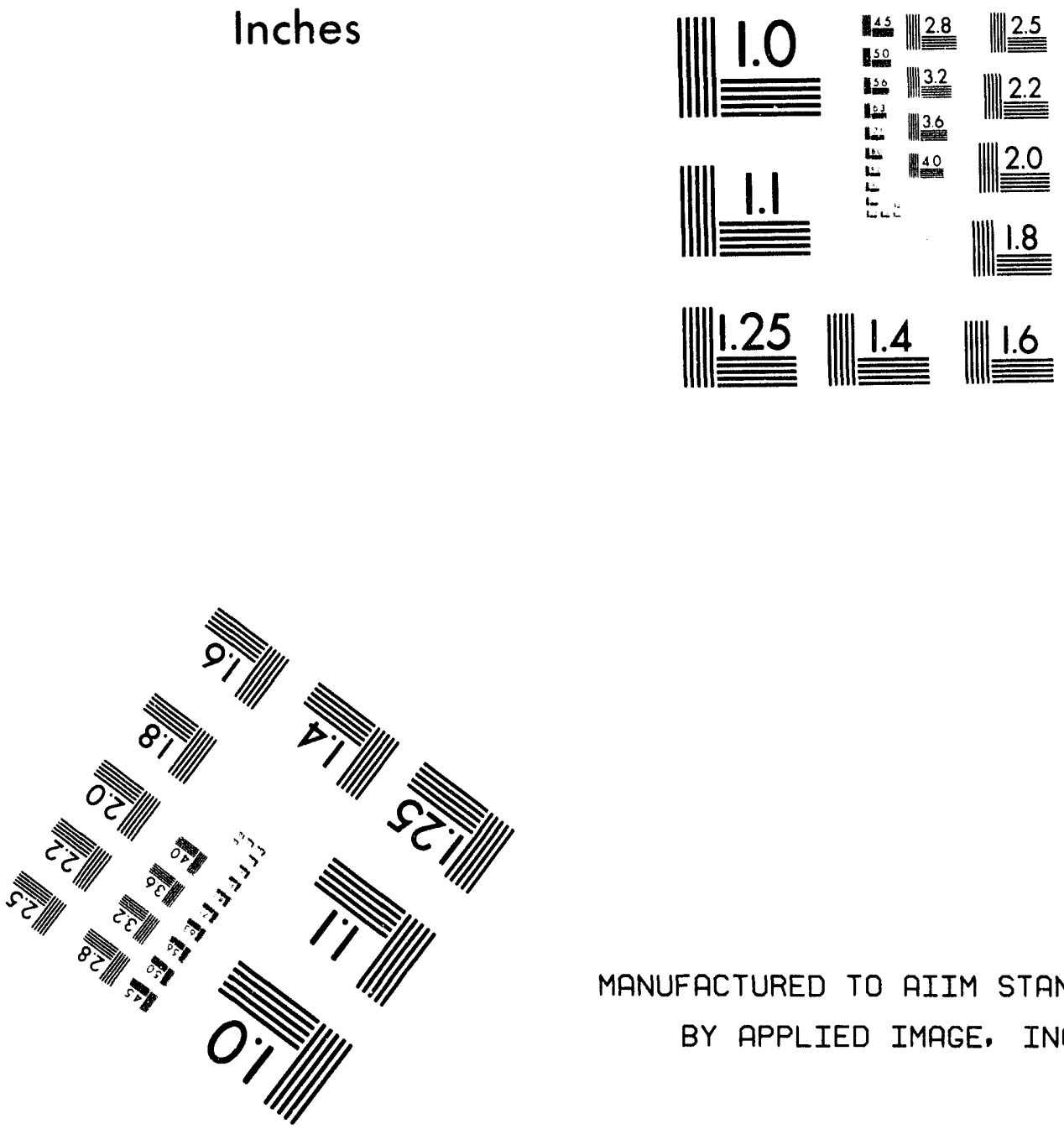

MANUFACTURED TO AIIM STANDARDS

BY APPLIED IMAGE, INC.

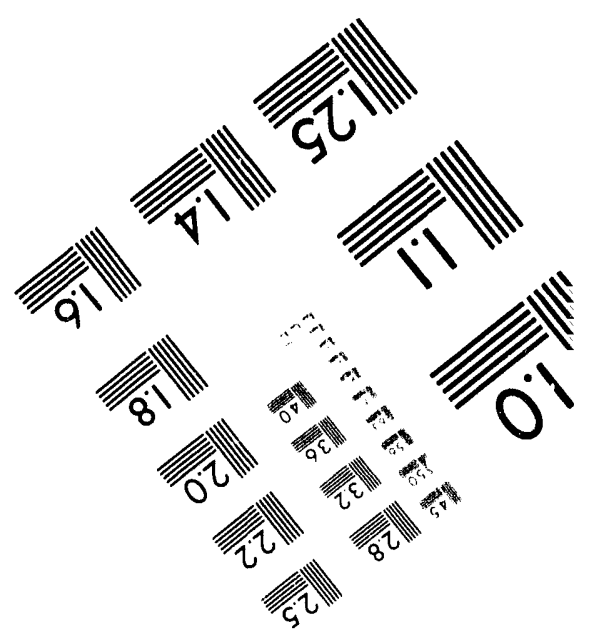



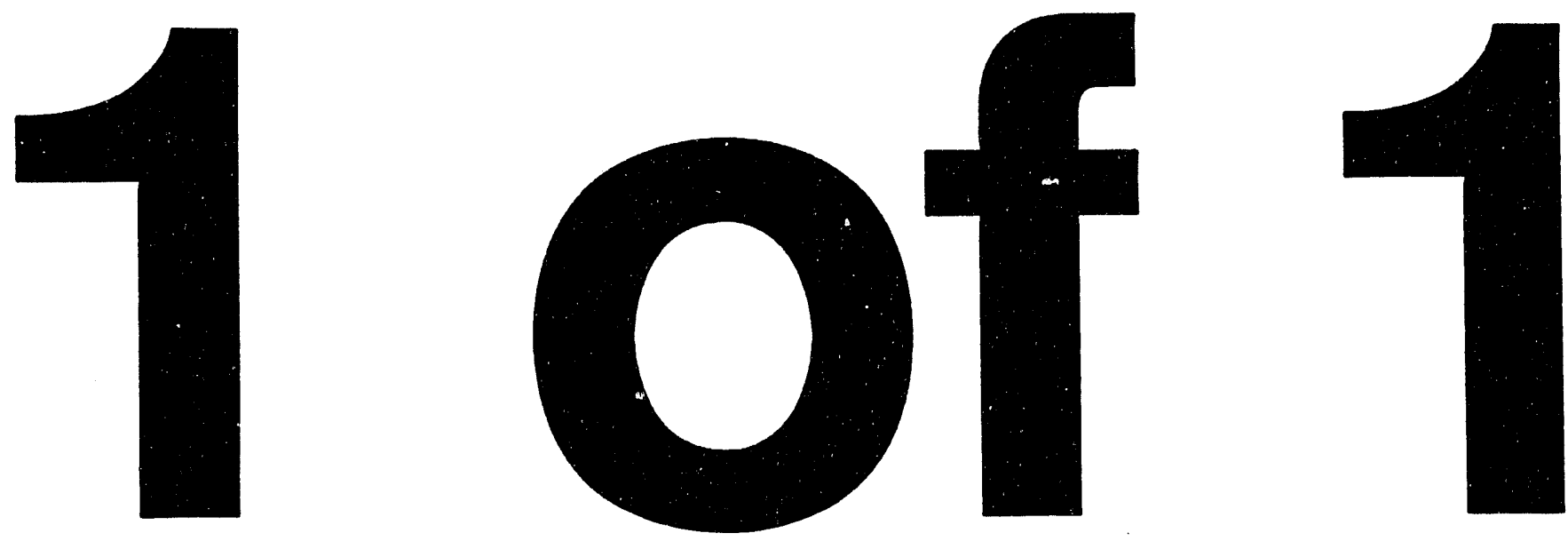


\title{
DOE $|A L| 62350-$ T
}

\section{EVALUATION OF IMPACTS AND MITIGATION ASSESSMENTS FOR THE UMTRA PROJECT: GUNNISON AND DURANGO PILOT STUDIES}

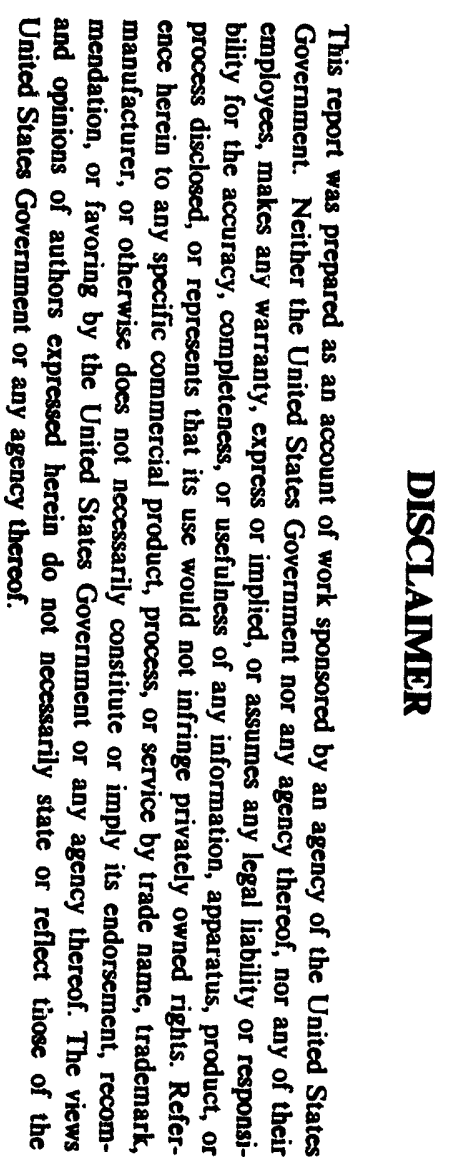

\section{RECEIVED \\ SEP 121994 \\ OSTI}

\section{Propared by} \\ for \\ Sandre J. Beranich \\ Southweet Environmental \\ 405 Carlielo NE \\ Abuquerque, Now Maxico 87106 \\ Subcontrect No. 05-62350-S-93-0017 \\ Jecobes Engineoring Group, Inc. \\ 2165 Louidena Blvd., NE, Sulte 10,000 \\ Albuquarquo, Now Maxico 87110
}

FINAL REPORT: Auguet 24, 1904 


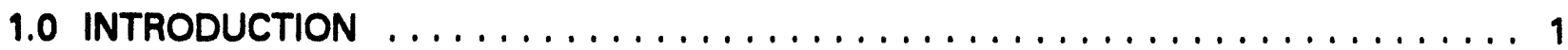

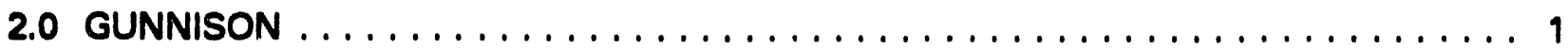

2.1 Demolition of Mill Buildings $\ldots \ldots \ldots \ldots \ldots \ldots \ldots \ldots \ldots \ldots \ldots \ldots$

2.2 Remedial Action of the Gunnison Processing Site $\ldots \ldots \ldots \ldots \ldots \ldots$

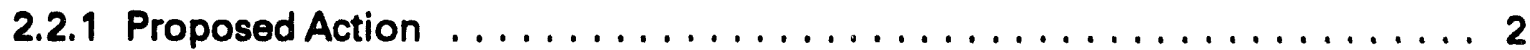

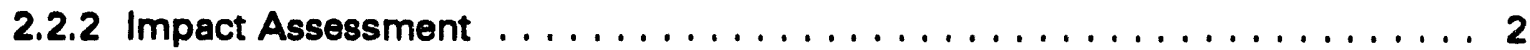

2.2.3 Mitigation Assessment $\ldots \ldots \ldots \ldots \ldots \ldots \ldots \ldots \ldots \ldots \ldots \ldots$

2.3 Provision of Water Supply System $\ldots \ldots \ldots \ldots \ldots \ldots \ldots \ldots \ldots$

2.3.1 Proposed Action $\ldots \ldots \ldots \ldots \ldots \ldots \ldots \ldots \ldots \ldots \ldots \ldots \ldots \ldots$

2.3 .2 Impact Assessment $\ldots \ldots \ldots \ldots \ldots \ldots \ldots \ldots \ldots \ldots \ldots \ldots \ldots \ldots$

2.3.3 Mitigation Assessment . . . . . . . . . . . . . . . . . . . . 4

2.4 Summary $\ldots \ldots \ldots \ldots \ldots \ldots \ldots \ldots \ldots \ldots \ldots \ldots \ldots \ldots \ldots \ldots \ldots \ldots$

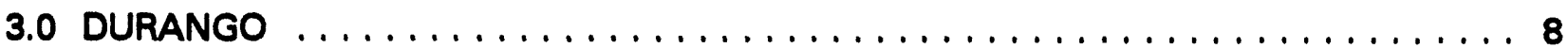

3.1 Description of the Remedial Action $\ldots \ldots \ldots \ldots \ldots \ldots \ldots \ldots$

3.2 Impact Assessment $\ldots \ldots \ldots \ldots \ldots \ldots \ldots \ldots \ldots \ldots \ldots \ldots$

3.3 Mitigation Assessment $\ldots \ldots \ldots \ldots \ldots \ldots \ldots \ldots \ldots \ldots \ldots \ldots \ldots$

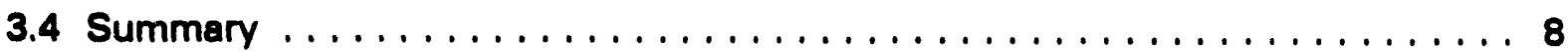

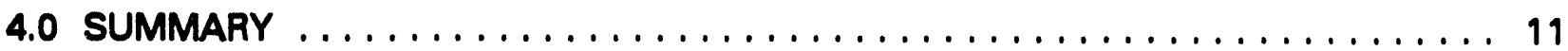

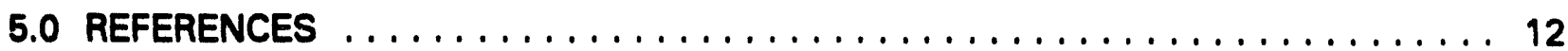




\section{LIST OF TABLES}

Iable

Pege

1 Identification of Impacts Associated with the Gunnison Remedial Action. . . . . . . . 5

2 Summary and Effectiveness of Mitigative Measures Associated with the Gunnison Remedial Action. . . . . . . . . . . . . . . . . . . . . . 6

3 Identification of Impacts Associated with the Durango Remedial Action . . . . . . . . 9

4 Summary and Effectiveness of Mitigative Measures Associated with the Durango Remedial Action . . . . . . . . . . . . . . . . . . . . . . 10 


\subsection{INTRODUCTION}

This report evaluates the impacts assessment and proposed mitigations provided in environmental documents prepared by Jacobs Engineering Group, Inc. (JEG) for the US Department of Energy's (DOE) Uranium Mill Tailings Remedial Action (UMTRA) Project. The projected impacts and proposed mitigations identified in UMTRA Project environmental documents were evaluated for two UMTRA Project sites that were selected by JEG. These sites are Gunnison and Durango, which are representative of currently active and inactive UMTRA Project sites, respectively. The methodology for this evaluation was provided in an earlier report: "Methodology to Evaluate the Accuracy of UMTRA Project Impact Assessments and the Effectiveness of Mitigative Measures Found in UMTRA Project Documents" (Southwest Environmental, 1994).

National Environmental Policy Act (NEPA) documentation was prepared by JEG for the remedial action at Durango and Gunnison as well as for the provision of an alternate water supply system at Gunnison. Additionally, environmental analysis, as required by the NEPA, was completed for mill site demolition at Gunnison, and for a new road related to the Durango remedial action.

The results in this report pertain only to the impact assessments prepared by the JEG Regulatory Compliance staff as a part of the NEPA compliance requirements. Similarly, the mitigative measures documented are those that were identified during the NEPA process.

It is recognized that subsequent to JEG documentation of the environmental impacts and development of mitigative measures, additional studies and reports have been prepared as part of the permitting process; the impacts and mitigative measures that were reported in those documents are not included in this report.

\subsection{GUNNISON}

In addition to the proposed remedial action for the Gunnison UMTRA Project, environmental documentation was prepared for demolition of the mill buildings at the processing site and for the provision of a water supply system for the residents of a subdivision downgradient from the processing site. Each of these projects are addressed separately.

\subsection{Demolition of Mill Buildings}

A categorical exclusion (CX) was prepared to evaluate the impacts associated with the demolition of the mill buildings on the Gunnison processing site. The $\mathrm{CX}$ was approved by DOE in July 1991. The proposed action was to demolish existing structures on the processing site, which included 11 mill buildings, a water tuwer, underground storage tanks, concrete foundation pads, and the like. Additionally, the project included arrangements for the removal of all hazardous substances associated with the mill site. It was anticipated that due to demolition activities, there would be temporary increases in total suspended particulate concentrations and therefore, a Colorado Air Emissions Permit would be obtained prior to any ground-disturbing activities. In addition, due to the use of heavy equipment, temporary increases in noise levels were anticipated. 
The demolition was conducted in 1991 and no additional impacts were noted; mitigation was not required (E rickson, 1994).

\subsection{Remedial Action of the Gunnison Processing Site}

\section{2 .1 Proposed Action}

The proposed remedial action was to remove all contaminated materials found within the designated Gunnison site boundary or associated with the processing site and to stabilize them at the Landfill Disposal site, approximately six air miles east of the processing site. The contaminated materials were to be buried and covered with layers of rock and soil. It was anticipated that 92 acres would be permanently transferred from the current land owner (Bureau of Land Management (BLM)) to the DOE. The project included the upgrading of a primitive track to a road capable of carrying haul truck traffic. A more detailed description of the proposed action is found in the Environmental Assessment (EA) of the remedial action (DOE, 1992).

Elements of the proposed action were verified through conversation with the JEG site manager and Morrison Knudsen-Ferguson (MK-F) site manager. With one minor exception, all elements were consistent with the proposed action evaluated in the EA (Ennis, 1994; McBee, 1994).

\subsubsection{Impact Assessment}

Table 1 summarizes the significant impacts identified in the EA for the remedial action. At the time of this writing, the analysis of the impacts in the EA is accurate. However, the Gunnison County planner has indicated that assessment of housing impacts was understated in the Gunnison EA. Further analysis does not substantiate that the UMTRA Project has impacted housing in Gunnison. In 1993, there were an estimated 76 workers on the UMTRA Project, of which 44 workers were considered to be local and thus not in need of housing. Thirty-two workers would have required housing. Only two workers indicated that they were sharing accommodations (Southwest Environmental, 1993). Although housing may not be readily available in Gunnison, it is likely that housing for 32 workers is available within a one-hour commute of Gunnison.

Impacts related to sage grouse were considered controversial at the time the EA was prepared and apparently are still controversial. During the Spring 1994 sage grouse count, it was determined that fewer male grouse were in attendance at leks than were previously noted. It is unknown at this time if there were other factors present that may have influenced the recorded number of males (eg, the weather was poor on the day of the count). The total impact to sage grouse and use of leks in the vicinity of the disposal site will not be known for several years after the completion of the remedial action.

A small portion of the haul route parallels the Panoview subdivision. In order to minimize noise impacts to the residents of Panoview, the Gunnison County Planning Commission Land Use Permit required a work day period of 6 AM to 7 PM. The number of haul truck trips was based on this day length and the assumption that the remedial action would be completed in three years. During 1993, innovative measures 
were taken to reduce the number of haul truck trips; these measures were not effective and resulted in a need for additional haul time that was not anticipated in the EA. In 1994, Gunnison County granted a change to the work schedule and allowed the contractor the option to work longer days. The residents of the Panoview subdivision did not object. The total number of haul truck trips as compared to the number estimated for impact assessment purposes is not available at this time.

The following individuals or agencies were contacted in support of impact assessment: JEG staff as follows: Chuck Burt for wildlife, wetland, and vegetation impacts; John McBee, Gunnison Site Manager for JEG; Tom Spezze, Colorado Division of Wildlife (DOW); Joanne Williams, Gunnison County Planner; Gary Tomsic, Gunnison County Manager; John Ennis, MK-F Gunnison Project Site Manager; and Alan Erickson, MK-F Gunnison site engineer.

\subsubsection{Mitigation Assessment}

Mitigative measures that were identified in the EA are listed on Table 2. The majority of the mitigative measures apply to activities that will occur after the completion of the remedial action. At the time of this writing, DOE has completed all applicable mitigations. Further evaluation of this element is required after the completion of the remedial action.

In addition to measures stated in the EA, a large number of additional, very specific mitigative measures are required by Gunnison County and the BLM as a part of their permitting requirements.

\subsection{Provision of Water Supply System}

\subsubsection{Proposed Action}

The proposed action was to provide a water supply system to residents of the Dos Rios Subdivision. Water was to be pumped from the Gunnison River through use of an intake system. Water pipelines were to convey the water beneath or adjacent to roads in the Dos Rios Subdivision, along Goodwin Lane, and to a gravel company south of the processing site. The system components included buried pipeline, service lines to individual residences, an intake structure, and a water tank reservoir. It was anticipated that all work would begin in 1991 and would be completed by the end of 1992.

There were a few minor changes from the proposed action identified in the EA; one change was related to the locations of the four river crossings. The locations of two river crossings did not change; however, the river crossing at the intake structure was moved about 100 feet north and the southern river crossing was eliminated and replaced by crossing the river along an existing bridge. Additionally, the water storage tank was relocated about 0.5 mile south of its projected location. There were also minor pipeline realignments that incorporated efficiencies and are not considered significant.

A possible impact omission was identified by the Gunnison County Manager who oversaw and coordinated construction of the water supply system for Gunnison County. He commented that it didn't appear that trout habitat at the river crossings 
was addressed in the EA and that the Gunnison River is an excellent trout fishery (Tomsic, 1994). Impacts to the Gunnison River trout fishery were not identified in the EA or during the EA process.

The water supply project began in 1992 and actual construction of the pipeline was not completed until 1993. All service lines are scheduled to be completed by the end of 1994. Due to the large number of coordinating entities (eg, DOE, State of Colorado, Gunnison, and the like), this project did not begin on schedule (McBee, 1994).

\subsubsection{Impact Assessment}

The only potentially significant impact that was determined through the EA process was the potential impact to spawning salmon in the Gunnison River. Coffer dams were used for the river crossings, es required; spawning salmon counts upstream from the river crossings did not indicate that any damage to salmon populations had occurred (Spezze, 1994).

\subsubsection{Mitigation Assessment}

As part of the 404 permitting process, restoration of wetland habitat was required after the completion of the proposed action. A small acreage $(0.46$ acre) of wetland habitat was anticipated to be disturbed while laying the pipeline. As of the time of this writing, no wetland restoration has been completed (Burt, 1994; Tomsic, 1994). Further tracking of this mitigative measure is necessary.

\subsection{Summary}

The results of the analysis of the Gunnison proposed actions do not indicate significant inaccuracies in impact analysis or projection. The changes that occurred are within the standard operating efficiencies of construction projects. Impacts related to the water supply system were not quantified (with the exception of the estimated wetland area disturbance) and further evaluation is, therefore unnecessary.

The actual quantification of the impacts that are or have occurred related to the remedial action is not possible until this action is complete. The assessment of the mitigative measures associated with the remedial action will similarly have to wait until completion of all activities and an additional period of time to ensure that all resource components have had an adequate recovery period. DOE has complied in proposing mitigative measures and, when applicable, is doing or has completed the required mitigation. 
Teble 1. Identficeetion of Impects Acoocieted wtth the Gunnleon Remediel Action.

\begin{tabular}{|c|c|c|c|c|c|}
\hline $\begin{array}{l}\text { Amoures } \\
\text { Componient }\end{array}$ & Imperet & $\begin{array}{l}\text { Was Impect } \\
\text { Predicted }\end{array}$ & $\begin{array}{l}\text { Wes } \\
\text { Ouallyyiouanthy of } \\
\text { Impect Accuratchy } \\
\text { Predicted? }\end{array}$ & Commint & $\begin{array}{l}\text { Achenence } \\
\text { Documents }\end{array}$ \\
\hline Wildlife & Sege grouse lek abendornment & Yes & Full impect unknown & $\begin{array}{l}\text { Full impact can only be determined after } \\
\text { completion of the remedial action }\end{array}$ & $\begin{array}{l}\text { DOE, 1992: } \\
\text { Spezee, } 1994\end{array}$ \\
\hline Transportation & $\begin{array}{l}\text { Estimste of truck trips to haul } \\
\text { tailings }\end{array}$ & res & Full impact unknown & Construction schedule has chenged & $\begin{array}{l}\text { DOE, 1992; } \\
\text { Ennis, 1994 }\end{array}$ \\
\hline Socioeconomics & Work force projections & Yes & Full impact unknown & $\begin{array}{l}\text { The average work force was projected as } \\
100 \text {; to date, the work force is averaging } \\
140-165 \text { individuals }\end{array}$ & $\begin{array}{l}\text { DOE, 1992; } \\
\text { Erickson, } 1994\end{array}$ \\
\hline
\end{tabular}




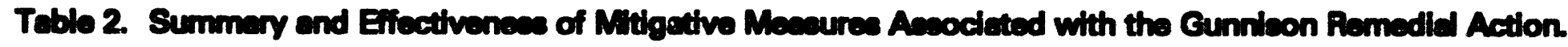

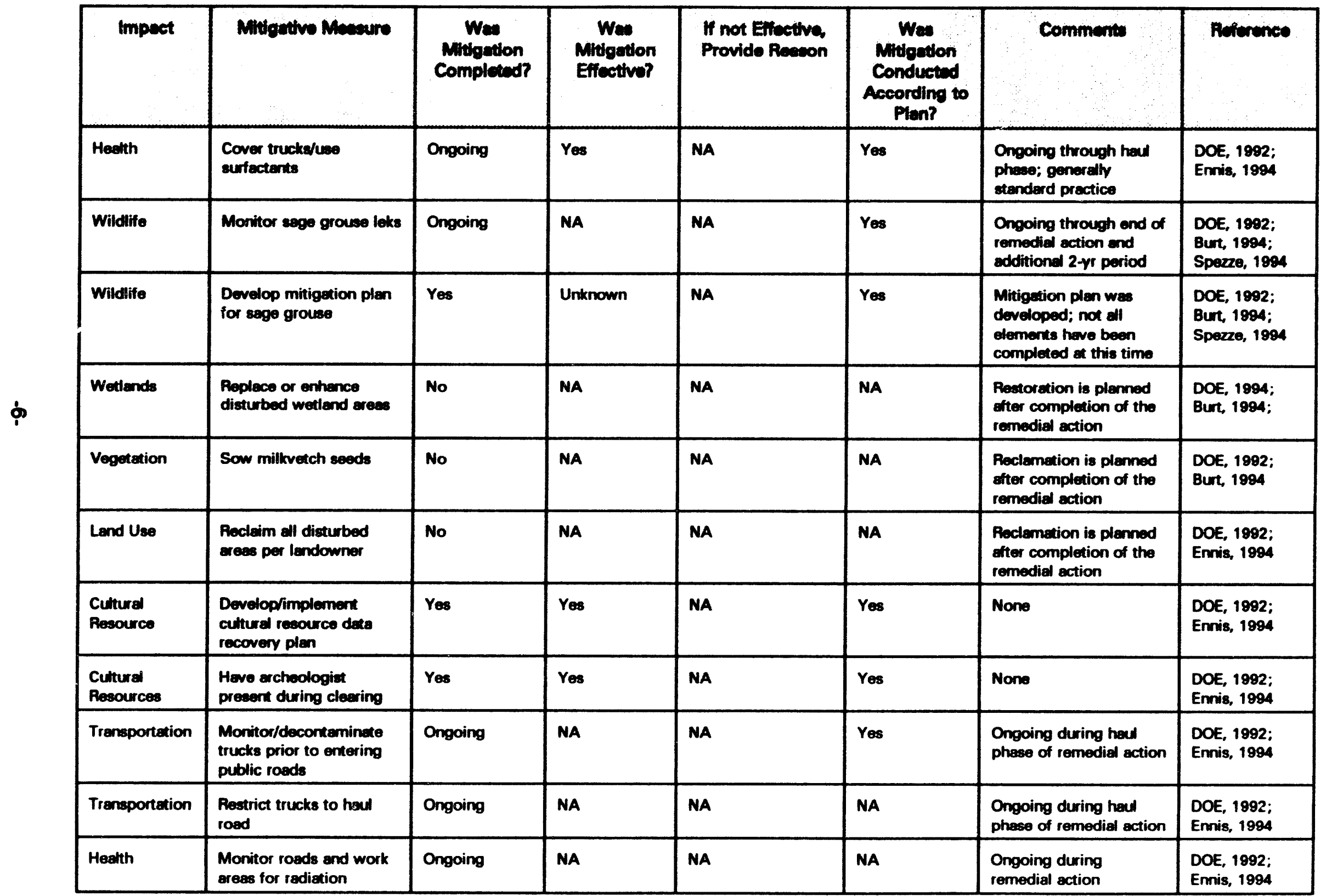


Table 2. Summery and Effectivenese of Mitigattvo Moesures Aseociated with the Gunnison Remedial Action (Concluded)

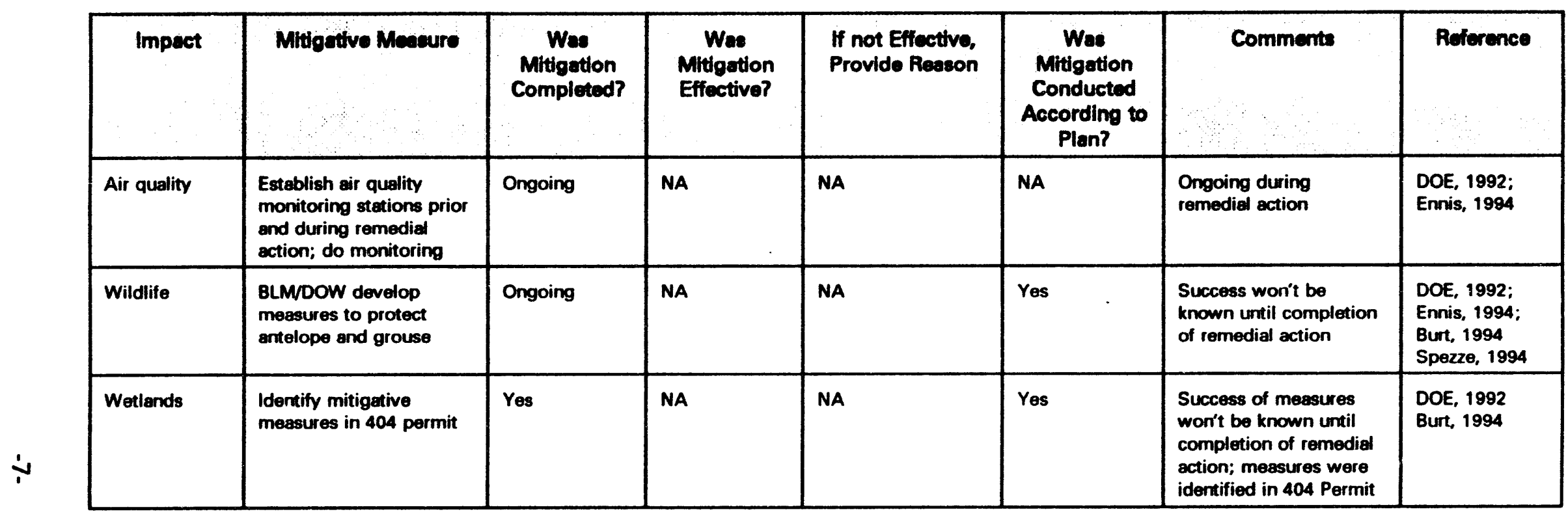




\subsection{DURANGO}

The Durango remedial action was begin in 1987 and completad in 1991. In addition to the Environmental Impact Statement (EIS), an environmental analysis of the Wheeler Haul Road was completed

\subsection{Description of the Remedial Action}

The Durango remedial action consisted of excavating and moving all contaminated materials associated with the Durango processing and mill site to the Bodo Canyon disposal site, approximately 3.5 road miles southwest of the Durango mill site. The contaminated materials were moved by covered haul trucks on constructed haul roads that were limited but not restricted to project use. The contaminated materials were buried and covered with a combination of rock and soil. At the time of the environmental assessment of the proposed action, wild life issues were considered significant because the disposal site was located within a designated wildlife area that was managed and owned by the State of Colorado.

Due to the length of time since completion of the remedial action, it can only be stated that the remedial action described in the EIS was followed and there are no known significant changes (Thomson, 1994).

Subsequent to publication of the EIS, a borrow source was identified 4.5 miles from the disposal site. Two roads were identified for transportation use; both required upgrading and resurfacing. An environmental analysis was prepared to determine whether or not the EIS would need to be supplemented. It was determined in the analysis that the impacts associated with this action would be less severe than those identified in the EIS for a borrow source that had been evaluated for project use and subsequently was dropped from further consideration. Supplementing the EIS was determined to be unnecessary (DOE, 1987).

\subsection{Impact Assessment}

Table 3 summarizes the significant impacts identified in the EIS. No additional impacts are known to have occurred during or as a result of the remedial action. It is unknown if the quantitative assessment of impacts is accurate. Many elements that were quantified in the EIS were not quantified in the field (eg total suspended particulates). Other values, such as the exact amount of land that was disturbed would need to be verified with a survey.

\subsection{Mitigation Assessment}

Mitigative measures that were identified during the environmental assessment phase are shown in Table 4. All measures were carried out as described.

\subsection{Summary}

Impacts and mitigative measures were compared to those identified in the Durango site EIS and other documents and found to represent accurately the known impacts and mitigative measures conducted for the Durango site. 
Table 3. Identification of Impects Aceocleted whth the Durango Remedial Action.

\begin{tabular}{|c|c|c|c|c|c|}
\hline $\begin{array}{l}\text { Anowirces } \\
\text { Component }\end{array}$ & Impect & Was Impect Predicud? & 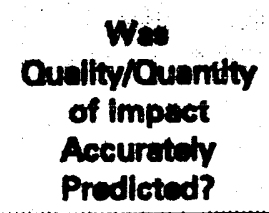 & Commarte & Potiminew \\
\hline Nilineral Resources & $\begin{array}{l}\text { Loss of } 400,000 \text { tons of } \\
\text { cosl resource lost }\end{array}$ & Yes & Unknown & Cannot be determined & $D O E, 1965$ \\
\hline Wildifie & $\begin{array}{l}\text { Increase in big game } \\
\text { collisions }\end{array}$ & Yes & No & $\begin{array}{l}\text { There were no big game } \\
\text { collisions }\end{array}$ & $\begin{array}{l}\text { DOE, } 1985 \\
\text { Thomson, } 1994\end{array}$ \\
\hline Wildifife & $\begin{array}{l}\text { Loss/alteration of } 60 \\
\text { acres of prime wildlife } \\
\text { habitat }\end{array}$ & Yes & Unknown & $\begin{array}{l}\text { Would need survey to } \\
\text { determine }\end{array}$ & DOE, 1985 \\
\hline Socioeconomic & $\begin{array}{l}\text { Creation of } 71 \text { short- } \\
\text { term jobs }\end{array}$ & Yes & No & $\begin{array}{l}\text { Average work force of } \\
120 \text { and peak of } 188\end{array}$ & $\begin{array}{l}\text { DOE, } 1985 \\
\text { Thomson, } 1991 \\
\end{array}$ \\
\hline Socioeconomic & $\begin{array}{l}\text { Maximum of } 180 \text { people } \\
\text { move to Durango }\end{array}$ & Yes & No & $\begin{array}{l}\text { Estimated that } 16 \% \text { (or } \\
20-30 \text { workers) relocated } \\
\text { to Durango and area } \\
\text { towns; maximum of } 150 \\
\text { people if each relocated } \\
\text { worker had spouse and } 3 \\
\text { children }\end{array}$ & $\begin{array}{l}\text { DOE, 1985; } \\
\text { Thomson, } 1991\end{array}$ \\
\hline Cultural resources & $\begin{array}{l}\text { Poss. destroy } 9 \text { cultural } \\
\text { resource sites eligible } \\
\text { for nomination to the } \\
\text { National Register of } \\
\text { Historic Places }\end{array}$ & Yes & Yes & $\begin{array}{l}\text { All sites were excavated } \\
\text { and data recovered prior } \\
\text { to the remedial action }\end{array}$ & $\begin{array}{l}\text { DOE, 1985; } \\
\text { DOE, } 1987\end{array}$ \\
\hline Socioeconomic & $\begin{array}{l}\text { Total Project cost of } \\
\$ 26.3 \text { million }\end{array}$ & Yes & No & $\begin{array}{l}\text { Project costs were } \\
\text { higher; construction only } \\
\text { cost was } \$ 27 \text { million }\end{array}$ & $\begin{array}{l}\text { DOE, 1985; } \\
\text { Thomson, } 1994\end{array}$ \\
\hline
\end{tabular}


Tablo 4. Summary and Effectivences of Mitigethe Moceures Aceocleted with tho Durengo Rernedid Action.

\begin{tabular}{|c|c|c|c|c|c|c|c|}
\hline Impact & Mitostwe Moeseure & $\begin{array}{l}\text { Wes } \\
\text { Mitigetion } \\
\text { Complated? }\end{array}$ & $\begin{array}{l}\text { Wow } \\
\text { Mitiontion } \\
\text { Effective? }\end{array}$ & $\begin{array}{l}\text { If not Encettive, } \\
\text { Provide Remeon }\end{array}$ & $\begin{array}{l}\text { Wes } \\
\text { Mitigntion } \\
\text { Conducted } \\
\text { According to } \\
\text { Plan? }\end{array}$ & Commente & Rulerences \\
\hline Hosth & $\begin{array}{l}\text { Cover trucke/uee } \\
\text { surfecterta/stop work } \\
\text { during high wind }\end{array}$ & Yos & Yes & NA & Yes & None & $\begin{array}{l}\text { DOE, 1985; } \\
\text { Thomson, } 1994\end{array}$ \\
\hline Hoelth & $\begin{array}{l}\text { Deconteminete trucks } \\
\text { before leaving site }\end{array}$ & Yes & Yes & NA & Yes & None & $\begin{array}{l}\text { DOE, 1985; } \\
\text { Thomson, } 1994\end{array}$ \\
\hline Groundwoter & $\begin{array}{l}\text { Use diversion ditches } \\
\text { Upgradient from work } \\
\text { aress }\end{array}$ & Yes & Yes & NA & Yes & None & $\begin{array}{l}\text { DOE, 1985; } \\
\text { Thomson, } 1994\end{array}$ \\
\hline Transportation & $\begin{array}{l}\text { Construct now houl } \\
\text { roed to minimize use } \\
\text { of US } 160\end{array}$ & Yos & Yes & NA & Yes & None & $\begin{array}{l}\text { DOE, 1985; } \\
\text { Thomson, } 1994\end{array}$ \\
\hline Wildlife & $\begin{array}{l}\text { Develop wildlife } \\
\text { mitigation plan prior } \\
\text { to stert of remedial } \\
\text { action }\end{array}$ & Yes & Yes & NA & Yes & None & $\begin{array}{l}\text { DOE, 1985; } \\
\text { Hoover et. al. } 1985\end{array}$ \\
\hline
\end{tabular}




\subsection{SUMMARY}

There are few significant impacts associated with the UMTRA Project remedial actions. The major impact is the removal of potential public health risks by removing the source of the potential health risk. The effectiveness of the UMTRA Project remedial actions to do this is difficult to confirm due to the length of time (perhaps several generations) required to determine if there are changes in public health in the site areas. The requirements of a large number of local and county commissions and state and Federal agencies establish extensive checks and balances resulting in a conservative estimation of impacts and mitigation requirements. The long term effect of the UMTRA Projects cannot be established in a few years. In the case of Gunnison, growth within the area is acting synergistically with the impacts associated with the UMTRA Project; long-term impacts will be hard to quantify. In Durango, there was a significant public and agency concern that there would be impacts to the town, wildlife, and cultural resources from the remedial action. Local concerns prior to and during the Durango remedial action were responded to by establishing a local task force to coordinate and respond to concerns and issues raised by local citizens. Cultural resource concerns were addressed by data recovery programs in conjunction with the approval of the State of Colorado Historic Preservation Office. Wildlife concerns were addressed by reaching agreement with the Colorado Division of Wildlife as to appropriatemitigation. Today, Durango is booming in response to many growth factors. There is no evidence that the remediation of the Durango mill site caused or inhibited growth; growth has been steady since the late 1980 's.

Proposed impacts for the Durango and Gunnison UMTRA Project sites were evaluated for accuracy and determined to be within the limits of accuracy available at the time the environmental documentation was prepared. The effectiveness of the proposed mitigations cannot be reasonably determined at this time. The mitigations proposed for Durango are known to have been conducted, but no follow-up appears to have taken place. Mitigations in response to agency requirements are often tracked by the applicable agency at the time they are carried out. In the case of the Gunnison water supply system, the small amount 10.46 acre) of wetland restoration required by the EA has not as yet been addressed. The majority of the mitigations associated with the Gunnison remedial action will not be carried out until after the completion of the remedial action in 1995.

The use of one methodology to evaluate the accuracy of impact projections and mitigations is consistent with sound environmental management. It is recommended that development of a 'call-up' system to track dates of mitigation requirements for all sites would clarify the status of mitigation at any time. The large number of site requirements may obscure the need for specific actions.

Use of the impacts analysis and mitigation verifications has many applications, some of which include enhanced public relations, refinement of impact analysis, and usefulness in providing guidance on new projects. This methodology does not address the large number of mitigation requirements of the coordinating agencies. It is the coordinating agencies who are directly involved with the resource management that actually provide the oversight that ensures that all mitigations are followed. 


\subsection{REFERENCES}

Burt, Chuck, 1994. Wildlife biologist, UMTRA Project, Jacobs Engineering Group, Inc. (JEG), Albuquerque, New Mexico, personal communications with Sandra Beranich, Southwest Environmental, Albuquerque, New Mexico, dated June 24, August 17 and 23, 1994.

CASA (Complete Archaeological Service Associates), 1988. Archaeological Investigations in the Bodo Cenvon Area, La Plata County. Colorade, UMTRA Archaeological Report 25, prepared by CASA, Cortez, Colorado for JEG, Albuquerque, New Mexico, January 11, 1988.

DOE (US Department of Energy), 1985. Remedial Actions at the Former Vanadium Corporation of America Uranium Mill Site. Durango. La Plata County, Colorado, Final Environmental Impact Study, prepared by JEG, Albuquerque, New Mexico for DOE UMTRA Project Office, Albuquerque, New Mexico, DOE/EIS-011F, October 1985.

DOE, 1987. "Wheeler Haul Road Environmental Analysis", prepared by JEG, Albuquerque, New Mexico for DOE UMTRA Project Office, Albuquerque, New Mexico, no date.

DOE, 1992. Environmental Assessment of Remedial Actions at the Gunnison Uranium Mill Tailings Site Near Gunnison, Colorado, DOE/EA-0376; prepared by JEG, Albuquerque, New Mexico for DOE UMTRA Project Office, Albuquerque, New Mexico, February 1992.

Ennis, John, 1994. MK-F site manager, Gunnison UMTRA Project Site, Gunnison, Colorado, personal communication with Sandra Beranich, Southwest Environmental, Albuquerque, New Mexico, dated June 24, 1994.

Erickson, Alan, 1994. MK-F site engineer, Gunnison UMTRA Project site, Gunnison, Colorado, personal communication with Sandra Beranich, Southwest Environmental, Albuquerque, New Mexico, dated August 10, 1994.

Hoover et. al. (Hoover, Robert and Associates), 1985. "Wildlife Mitigation Plan, Uranium Mill Tailings Remedial Action Project, Durango, Colorado", prepared by Hoover et. al., Arvada, Colorado for JEG, Albuquerque, New Mexico, dated September 24, 1985.

McBee, John, 1994. JEG Gunnison UMTRA Project Site Manager, Albuquerque, New Mexico, personal communication with Sandra Beranich, Southwest Environmental, Albuquerque, New Mexico, dated June 24, 1994.

Southwest Environmental, 1993. "Assessment of Employment Related to the Department of Energy Uranium Mill Tailings Remedial Actions, State of Colorado" prepared by Sandra Beranich for Southwest Environmental, Albuquerque, New Mexico for JEG, Albuquerque, New Mexico, report dated November 1993.

Southwest Environmental, 1994. "Methodology to Evaluate the Accuracy of UMTRA Project Impact Assessments and the Effectiveness of Mitigative Measures Found in UMTRA Project Documents", prepared by Sandra Beranich for Southwest Environmental, Albuquerque, New Mexico for JEG, Albuquerque, New Mexico, report dated February 24, 1994. 
Spezze, Tom, 1994. Wildlife biologist, Colorado Division of Wildlife, Gunnison, Colorado, personal communication with Sandra Beranich, Solsthwest Environmental, Albuquerque, New Mexico, dated June 27, 1994.

Thomson, Mark, 1991. MK-F Gunnison UMTRA Project Site Manager, Gunnison, Colorado, personal communication with Sandra Beranich, Environmental Scientist, JEG, Albuquerque, New Mexico, dated December 12, 1991.

Thomson, Mark, 1994. MK-F site engineer, Albuquerque, New Mexico, personal communication with Sandra Beranich, Southwest Environmental, Albuquerque, New Mexico, dated June 27, 1994.

Tomsic, Gary, 1994, Gunnison County Manager, Gunnison, Colorado, personal communication with Sandra Beranich, Southwest Environmental, Albuquerque, New Mexico, dated August 1. 1994.

Williams, Joanne, 1994. Gunnison County Planning Department, Gunnison, Colorado, personal communication with Sandra Beranich, Southwest Environmental, Albuquerque, New Mexico, dated August 1, 1994. 

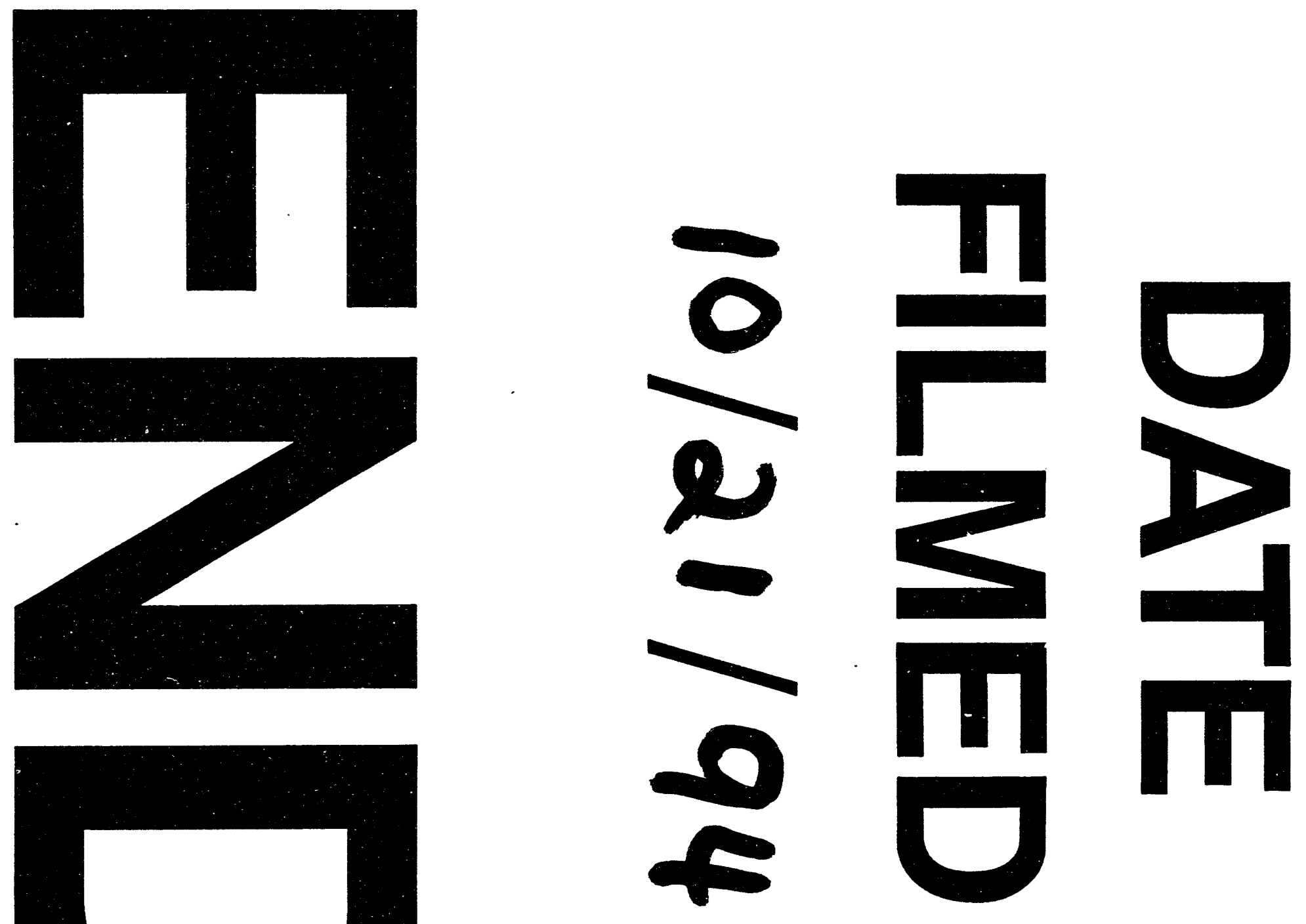
